\title{
The Assay of Influenza Virus Particles by Haemagglutination and Electron Microscopy
}

\author{
By D. A. J. TYRRELL aNd R. C. VALENTINE \\ The Virus Research Laboratory of the University of Sheffield, \\ Lodge Moor Hospital, Sheffield and The National Institute for Medical \\ Research, Mill Hill, London, N.W. 7
}

SUMMARY : A comparison of an indirect method of counting virus particles (i.e. the 'absolute assay' haemagglutination method) with direct electron-microscope counts showed that the indirect method underestimated the total virus particle count by a factor of about 10. Details of technique and possible sources of error in making counts are discussed.

There has been in recent years increasing interest in quantitative studies of influenza virus, and for this reason accurate and simple ways of assaying the virus have been sought. It is agreed that the haemagglutination titre given by the pattern test is in many respects a stable and accurate index of the amount of virus in a preparation. Published data based on electron-microscopic counts show that there is about one virus particle per red cell in mixtures of virus and red cells which show partial agglutination with this test (Werner \& Schlesinger, 1954; Donald \& Isaacs, 1954; Isaacs \& Donald, 1955).

A modification of the haemagglutination test has been introduced under the name of an 'absolute assay' (Levine, Puck \& Sagik, 1953). A mixture of red cells and virus is allowed to sediment in a colorimeter tube, and the change of concentration of red cells in the middle of the tube is followed by a simple colorimeter. From the data the number of rapidly settling red cells is calculated. The number of virus particles is calculated on the assumption that the rapidly settling cells represent pairs of red cells held together by one virus particle. The published data indicated that the results of virus particle assays made in this way agreed with electron-microscope counts made by the spray technique. A similar absolute assay technique has been developed independently and used in extensive quantitative studies on the growth of viruses in the allantoic cavity (Horsfall, 1954).

Those workers who used the absolute assay technique reported that 1 or 2 virus particles may represent 1 egg-infective unit, whereas Donald \& Isaacs (1954) found 10 particles visible on electron microscopy for each egg-infective unit present and one particle per red cell at the conventional partial agglutination end-point of the pattern test.

The present investigation began when an attempt was made to prepare carefully standardized and highly infective seed for use in a study on neurotropic strains of influenza viruses. Preliminary investigations showed that there was a tenfold difference between estimates of the concentration of influenza virus particles calculated from haemagglutination data by the 
methods of the two groups of workers mentioned above. This is also evident from the data given in Table 1 of Levine et al. (1953). The methods were then critically examined and it is now concluded that calculations based on the 'absolute assay' method were erroneous.

\section{ME'THODS}

Virus strains. Influenza virus strains WS and NWS (Francis) were supplied by Dr Alice Moore of the Sloan-Kettering Institute, New York (Francis \& Moore, 1940). NWS (Stuart-Harris) was a strain passed in eggs and in chick embryo fibroblasts by Professor C. H. Stuart-Harris. MEL and N.MEL (a neurotropic recombinant of NWS (Stuart-Harris) and MEL described by Burnet \& Edney, 1951) were supplied by Dr A. Isaacs. KUNZ was an eggpassaged line of influenza $A$ isolated in Sheffield in 1948 and N-KUNZ was a neurotropic strain prepared with NWS and KUNZ by Dr J. C. Appleby (1952).

Buffered saline. Sodium chloride $(0.85 \%, \mathrm{w} / \mathrm{v})$ in $0.01 \mathrm{~m}-\mathrm{phosphate}$ buffer $(\mathrm{pH} \mathrm{7 \cdot 2).}$

Red cells. Washed hen red cells were suspended in buffered saline and used within a few days.

Propagation of viruses. The seed virus was diluted $10^{-4}$ or $10^{-5}$ and $0 \cdot 2 \mathrm{ml}$. inoculated to the allantoic cavity of 10- or 11-day chick embryo. Groups of eggs were chilled at $4 \mathrm{hr}$. intervals and the pooled fluids from each group titrated. The first pool which showed a high HA (haemagglutination) titre was subdivided and stored at $-70^{\circ}$.

Egg infectivity titrations. Groups of 4 eggs were inoculated with $\mathbf{3} \cdot \mathbf{1 6}$-fold (half $\log$ ) serial dilutions in chilled buffered saline. The eggs were chilled 2 or 3 days later and the fluids tested for the presence of haemagglutinins. Infectivity end-points were calculated by the method of Reed \& Muench (1938).

Haemagglutination titrations were carried out by the W.H.O. pattern method, the red cell concentration being obtained from direct counts on the suspension used.

Red-cell sedimentation method. Dilutions of virus were added in volumes of $0.5 \mathrm{ml}$. to standardized colorimeter tubes of $13 \mathrm{~mm}$. diameter. Ten or $9.5 \mathrm{ml}$. of $0.5 \%(\mathrm{v} / \mathrm{v})$ washed hen red cells was added. The tubes were mixed by inversion and placed under cover. The optical density was recorded on an EEL colorimeter with a green filter. The light beam passed about $35 \mathrm{~mm}$. below the meniscus. Readings were made at 10-30 min. intervals from about $1 \frac{1}{2}$ to $4 \frac{1}{2} \mathrm{hr}$. after the beginning of the experiment. Occasionally the distance which the cell boundary had dropped below the meniscus was measured with a Perspex ruler.

\section{RESULTS}

\section{Features of the red-cell sedimentation procedure}

Some general features of the results of sedimentation experiments are shown in Table 1 and Fig. 1 which are abstracted from the records of the titration of a pool of WS virus. This experiment was one of several carried out with the 
object of showing whether the sedimentation test behaved as would be anticipated from the theory of Levine et al. (1953) and Horsfall (1954). An effect on the rate of sedimentation is seen in the tubes with the first four dilutions (1/10-1/80) of virus. In the first two of these tubes $(1 / 10,1 / 20)$ all the cells were settling rapidly since the boundary was descending faster than the controls. However, in the dilutions $1 / 40$ and 1/80 the optical density was decreased but the boundary was descending as in the controls. In tubes such as these it is possible to assume that there is a mixture of single cells and rapidly settling agglutinated cells, and over the narrow range covered there appears to be direct proportionality between the amount of rapidly settling cells (Table 1, optical density column g minus optical density column c or d) and the amount of virus added.

Table 1. Observations on mixtures of hen red cells and influenza $A$ virus, strain WS, in colorimeter tubes. The relation of the increased rate of sedimentation of cells in the presence of virus to the agglutination pattern of sedimented cells

\begin{tabular}{|c|c|c|c|c|c|c|c|c|}
\hline \multirow[b]{2}{*}{ Measurement made } & \multirow[b]{2}{*}{$\begin{array}{c}\text { Time } \\
\text { (min.) }\end{array}$} & \multicolumn{6}{|c|}{ Dilution of virus } & \multirow{2}{*}{$\begin{array}{l}\text { Saline } \\
\text { control } \\
\mathrm{g}\end{array}$} \\
\hline & & $\begin{array}{c}1 / 10 \\
\mathbf{a}\end{array}$ & $\begin{array}{c}1 / 20 \\
b\end{array}$ & $\begin{array}{c}1 / 40 \\
\mathrm{c}\end{array}$ & $\begin{array}{c}1 / 80 \\
d\end{array}$ & $\begin{array}{c}1 / 160 \\
\mathrm{e}\end{array}$ & $\begin{array}{c}1 / 320 \\
\mathbf{f}\end{array}$ & \\
\hline Optical density & $\mathbf{0}$ & $0 \cdot 56$ & 0.57 & 0.57 & 0.57 & 0.57 & 0.58 & 0.58 \\
\hline Optical density & 124 & $0 \cdot 15$ & $0 \cdot \mathbf{2 3}$ & $0 \cdot 33$ & 0.43 & $0 \cdot 48$ & $0 \cdot 49$ & $0 \cdot 49$ \\
\hline $\begin{array}{l}\text { Distance boundary } \\
\text { sedimented }(\mathrm{cm} .)\end{array}$ & 135 & $2 \cdot 8$ & $2 \cdot 4$ & $\mathbf{2} \cdot \mathbf{3}$ & $2 \cdot 2$ & $2 \cdot 2$ & $2 \cdot 3$ & $\mathbf{2} \cdot \mathbf{3}$ \\
\hline Optical density & 205 & 0.04 & 0.04 & $0 \cdot 08$ & $0 \cdot 16$ & $0 \cdot 26$ & $0 \cdot 24$ & $\mathbf{0} \cdot \mathbf{2 4}$ \\
\hline $\begin{array}{l}\text { Distance boundary } \\
\text { sedimented }(\mathrm{cm} .)\end{array}$ & 207 & 6 & 4 & $3 \cdot 5$ & $\mathbf{3 \cdot 5}$ & $3 \cdot 3$ & $3 \cdot 3$ & $\mathbf{3} \cdot \mathbf{5}$ \\
\hline $\begin{array}{l}\text { Agglutination pattern } \\
\text { of sedimented cells }\end{array}$ & - & $++t$ & +++ & +++ & ++ & $\mathbf{0}$ & 0 & $\mathbf{0}$ \\
\hline
\end{tabular}

The proportion of rapidly settling cells was usually derived from a graph such as that in Fig. 1, in which a straight line was fitted by eye to points obtained by plotting optical density against time. It appeared that there were irregularities in the settling process in the early and late phases, and one rarely saw a clear-cut phase demonstrating the rapid settling of agglutinated cells in tubes containing virus. However, recordings made using the intermediate stages were reasonably consistent, and at times the settling curves suggested the pattern of converging lines expected theoretically (Fig. 1). Levine et al. (1953) mentioned curves of settling of virus + red-cell mixtures which were parallel to the control curve. This would not be expected from their theory since, if the boundary of single cells were descending at the same rate in the control and in the experimental tubes, they would pass through the light path at the same time and the optical density would reach zero at the same time in both tubes. If the curves were parallel, the ratio of sedimented to unsedimented cells would vary from point to point along the curves.

At the beginning of this experiment a $\mathbf{0 . 2 5} \mathrm{ml}$. sample was removed from each tube and allowed to form a pattern in a Perspex plate. The result is shown 
in the bottom row of Table 1 and indicates that the last mixture of red cells and virus which showed accelerated sedimentation also showed partial agglutination by the pattern method (i.e. represented the haemagglutination endpoint). A similar relationship between the end-points was noted in experiments with KUNZ, N-KUNZ, NWS (Francis), NWS (Stuart-Harris), MEL and N.MEL. (Egg infectivity titrations were carried out on all these fluids and the average ratio of EID 50 to 'absolute assay' particle counts was 1.3.) That

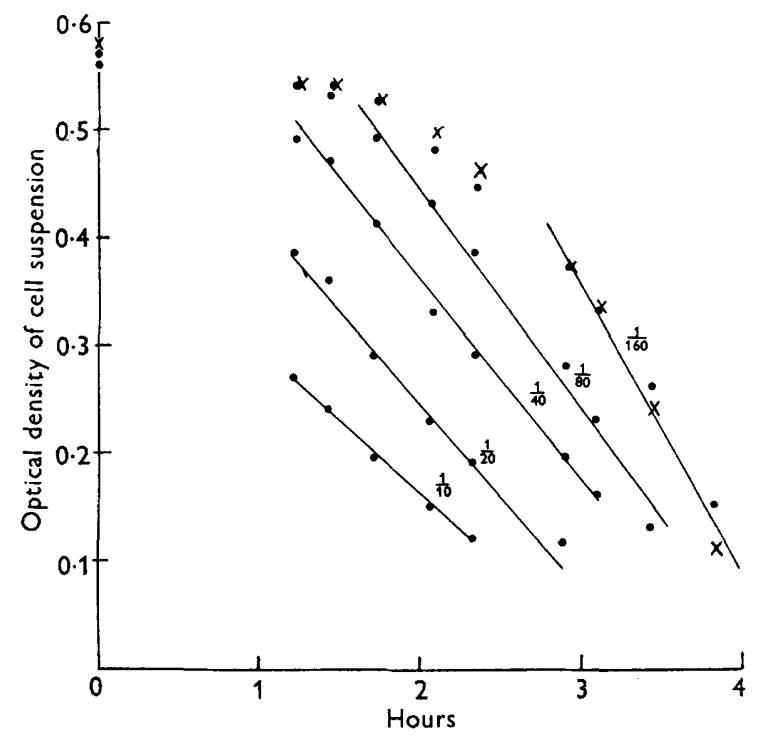

Fig. 1. Photoelectric colorimeter readings across the middle of 6 tubes during the sedimentation of mixtures of red cells and various dilutions of WS virus. $x-x$ indicates the control mixture without virus; $\bullet-\bullet$ indicates mixture virus + red cells. The initial dilution of virus is shown by each curve. More details are given in the text and in Table 1.

partial haemagglutination in the pattern test and an increased sedimentation rate in the 'absolute assay' should occur at the same dilution of virus indicates clearly that one of the methods of estimating the number of virus particles from haemagglutination data must be wrong. From the data of Donald \& Isaacs (1954) we should expect, at the pattern-test end-point, 1 virus particle for each red cell present in the mixture. But from the 'absolute assay' data on this same mixture Horsfall (1954) or Levine et al. (1953) would calculate that $33 \%$ of the cells are settling rapidly in doublets, and that therefore the number of virus particles is half $33 \%$ of the number of red cells, i.e. about 1 particle for each 6 cells present.

The relation between direct particle counts, standard haemagglutination titrations and the sedimentation method

An experiment was therefore carried out to determine the number of particles at the haemagglutination end-point for 5 different strains by counting the virus particles directly with the electron microscope by two techniques, 
the red-cell absorption method (Dawson \& Elford, 1949; Donald \& Isaacs, 1954) and the spray-drop method (Williams \& Backus, 1949). Seeds of WS, NWS and MEL were diluted $10^{-4}$, seeds of KUNZ and N.KUNZ were diluted $10^{-3}$. Nine-day eggs were inoculated with $0.2 \mathrm{ml}$. of these dilutions and the allantoic fluids harvested $24 \mathrm{hr}$. later. For each virus one clear fluid which gave a positive haemagglutination test was selected for study.

To determine the count by the red-cell method, a measured volume of the virus fluid was mixed with a known number of washed, saponin-lysed hen red cells (ghosts). The virus particles were almost completely adsorbed on these ghosts, the supernatant fluids in all cases showing less than $2 \%$ residual haemagglutinating activity. The mean number of particles/ghost was then found by electron microscopy. The only departure from the techniques described by Donald \& Isaacs (1954) was in counting virus particles on the upper and lower surfaces of each ghost as we were unable to distinguish the particles adsorbed on the top of the membrane. This is illustrated by Pl. 1. Pl. 1, fig. 1, shows a ghost before the preparation was metal-shadowed; there is sufficient contrast to identify the adsorbed virus particles and there can be no difference between those on the upper and lower surfaces of the membrane. Pl. 1, fig. 2, shows this ghost after metal-shadowing; the same particles are all to be seen and there is no clear distinction between their shadows to show which lie on top. Presumably the cell membrane is so thin that the particles on the underside push through it as the preparation dries down. Clear counts on all five virus fluids were made by this method.

Counts by the spray-drop method were made after dialysing $0.5 \mathrm{ml}$. of each virus fluid against $100 \mathrm{vol}$. distilled water for $18 \mathrm{hr}$. Haemagglutination titrations on the dialysed fluids did not differ significantly from those made before dialysis, and the fluids were then mixed with known numbers of polystyrene latex spheres and sprayed on to prepared grids without delay. The details of these techniques were as described in Luria, Williams \& Backus (1951). Some difficulties occurred in making these counts. By placing the fluid as harvested directly on specimen grids and examining them in the electron microscope, it was noticed that one strain (KUNZ) consistently gave fluids containing much debris in addition to the virus particles (Pl. 2, fig. 3), while all the other strains gave fluids almost entirely free from debris. Pl. 2, fig. 4, shows the appearance of the WS fluid. During dialysis of the KUNZ fluid, much of the debris precipitated; the spray drops, however, were filled with many tiny particles (Pl. 2, fig. 5). Very few typical virus particles were found in these drops, although, as already stated, the haemagglutination titre showed no decrease during the dialysis. For this reason spray counts were not made with the KUNZ strain; the NWS fluid was also unsuitable on account of its low titre. The other three strains gave satisfactory counts; Pl. 2, fig. 6, shows part of a spray drop of MEL.

The dispersion of particles in the spray drops was improved by more complete dialysis than that described, but it was found that the virus particles werc unstable in low salt concentrations. Thus on dialysing MEL for 4 days against two changes of water, the haemagglutination activity decreased more 
than 50 -fold to a titre of less than fifty. Despite this loss of titre, virus particles were still identifiable though some showed degenerative changes.

The results of these experiments are summarized in Table 2, which shows that there was reasonable parallelism between the results of all four measurements on the various fluids. The two methods of electron microscopy gave very similar particle counts, but these were 6- to 20-fold higher than those estimated by the 'absolute assay' procedure.

Table 2. Measurements on five allantoic fluids containing influenza virus. The discrepancy between the numbers of virus particles determined by electron microscope counts and by the red-cell sedimentation ('absolute assay') procedure

\begin{tabular}{|c|c|c|c|c|c|}
\hline \multirow[b]{2}{*}{ Strain } & \multirow[b]{2}{*}{$\begin{array}{l}\text { HA units* } \\
\text { per ml. }\end{array}$} & \multicolumn{3}{|c|}{$\begin{array}{l}\text { Electron microscope } \\
\text { particle counts }\end{array}$} & \multirow[b]{2}{*}{$\begin{array}{c}\text { Ratio: } \dagger \\
\text { EM particles } \\
\mathbf{H A}\end{array}$} \\
\hline & & $\begin{array}{l}\text { 'Absolute } \\
\text { assay' } \\
\text { particles } \\
\text { per ml. }\end{array}$ & $\begin{array}{l}\text { Red-cell } \\
\text { method } \\
\text { per ml. }\end{array}$ & $\begin{array}{l}\text { Spray } \\
\text { method } \\
\text { per ml. }\end{array}$ & \\
\hline Ws & 5200 & $8.5 \times 10^{9}$ & $53 \times 10^{9}$ & $60 \times 10^{9}$ & $1.1 \times 10^{7}$ \\
\hline NWS & 200 & $0.80 \times 10^{9}$ & $5.5 \times 10^{9}$ & $-\ddagger$ & $2.75 \times 10^{7}$ \\
\hline KUNZ & 1000 & $2 \cdot 3 \times 10^{9}$ & $14 \times 10^{9}$ & - & $1.4 \times 10^{7}$ \\
\hline N.KUNZ & 400 & $0.88 \times 10^{9}$ & $18 \times 10^{9}$ & $18 \times 10^{9}$ & $4.5 \times 10^{7}$ \\
\hline MEL & 2000 & $3.8 \times 10^{9}$ & $24 \times 10^{9}$ & $33 \times 10^{9}$ & $1.4 \times 10^{7}$ \\
\hline
\end{tabular}

* One HA unit gives partial agglutination with an equal vol. of $1 \%(\mathrm{v} / \mathrm{v})$ hen red cells $\left(2 \cdot 5 \times 10^{7}\right.$ cells $/ \mathrm{ml}$.).

$\uparrow$ Ratio $=$ particles by electron microscope count/haemagglutination units.

\$ Too few particles (NWS) or too much debris (KUNZ) to do accurate counts.

The ratio particles : haemagglutination units range from $1 \cdot 1 \times 10^{7}$ to $4.5 \times 10^{7}$ for the electron microscope counts on the various strains and, since the count of the red-cell suspension used was $2 \cdot 5 \times 10^{7}$, the ratio of virus particles to red cells at the partial agglutination end-point was about 1 , as previously found with other influenza A strains (Donald \& Isaacs, 1954).

In other experiments of this sort in which similar results were obtained a WS fluid was studied which had an infectivity titre of $10^{9 \cdot 7}$ and an 'absolute assay' particle count of $10^{9 \cdot 9}$. It could therefore be called a 'fully infectious fluid' (Horsfall, 1954), but the electron microscope count was $10^{11.0}$ showing that, despite agreement between the two titres, neither was a true measure of the number of virus particles present.

\section{DISCUSSION}

These experiments force upon us a very cautious and empirical attitude toward the deduction of virus particle counts from haemagglutination data. It seems that the haemagglutinating virus 'absolute assay' method is based on an unjustified assumption. The data indicate that either one virus particle cannot tie together two red cells, or perhaps, if it can do so, it has about a one in ten chance of doing so during the conduct of the experiment. It seems the mumps virus and influenza $\mathrm{C}$ virus particles are even less efficient in producing 
haemagglutination since they are present in two- or threefold higher concentration than influenza $\mathbf{A}$ particles at the agglutination end-point (Isaac \& Donald, 1955). There is suggestive evidence in our data that the particles of neurotropic strains of influenza virus may be less efficient than their parent strains in inducing haemagglutination. These differences may reflect differing affinities of the virus for red-cell receptors.

It is difficult to explain why Levine et al. (1953) obtained apparent confirmation of their theory from electron microscope counts. We note, however, that they used centrifuged and resuspended particles and only used the spray method. We have found that apparently simple manipulations like dialysis and storage may drastically decrease spray counts, and it is possible that technical factors of this sort might have affected the experiments of Levine $e t a l$.

The data indicate that the 'fully infectious seed' contains in fact many more virus particles than infectious units, but this is a discrepancy found generally among viruses (Luria, 1953), perhaps because not all particles reach susceptible cells or, if they do so, fail to initiate infection. These factors operate even when precautions are taken to avoid thermal inactivation of the virus after release from cells, and of course it is not known whether all virus particles are potentially infectious even immediately after release from a host cell. The data also indicate the need to recalculate and re-interpret work carried out by using the sedimentation techniques. For example, one of us (Tyrrell, 1955) calculated the yield of virus particles from chick embryo lung cells infected with the WS strain. The result given was just under $10^{3}$ particles/cell, whereas it would become $10^{4}$ particles/cell if calculated from either the sedimentation or pattern haemagglutination experiments, using the factors found in this investigation.

\section{REFERENCES}

Appleby, J. C. (1952). The isolation and properties of a modified strain of neurotropic influenza A virus. Brit. J. exp. Path. 33, 280.

Burnet, F. M. \& Edney, M. (1951). Recombinant viruses obtained from double infections with the influenza A viruses MEL and Neuro-WS. Aust. J. exp. Biol. med. Sci. 29, 353.

Dawson, I. M. \& Elfond, W. J. (1949). The investigation of influenza and related viruses in the electron microscope by a new technique. J. gen. Microbiol. 3, 298.

Donald, H. B. \& IsaAcs, A. (1954). Counts of influenza virus particles. J. gen. Microbiol. 10, 457.

Francis, Jun., T. \& Moore, A. E. (1940). A study of the neurotropic tendency in strains of the virus of epidemic influenza. J. exp. Med. 72, 717.

Horsfald, Jun., F. L. (1954). On the reproduction of influenza virus. Quantitative studies with procedures which enumerate infective and haemagglutinating virus particles. J. exp. Med. 100, 135.

IsaACs, A. \& Donald, H. B. (1955). Particle counts of haemagglutinating viruses. J. gen. Microbiol. 12, 241.

Levine, S., Puck, T. T. \& SAGik, B. P. (1953). An absolute method for assay of virus haemagglutinins. J. exp. Med. 98, 521.

Luria, S. E. (1953). General Virology, pp. 53 and 54. New York: John Wiley.

Luria, S. E., Williams, R. C. \& Backus, R. C. (1951). Electron micrographic counts of bacteriophage particles. J. Bact. 61, 179. 
Journal of General Microbiology, Vol. 16, No. 3
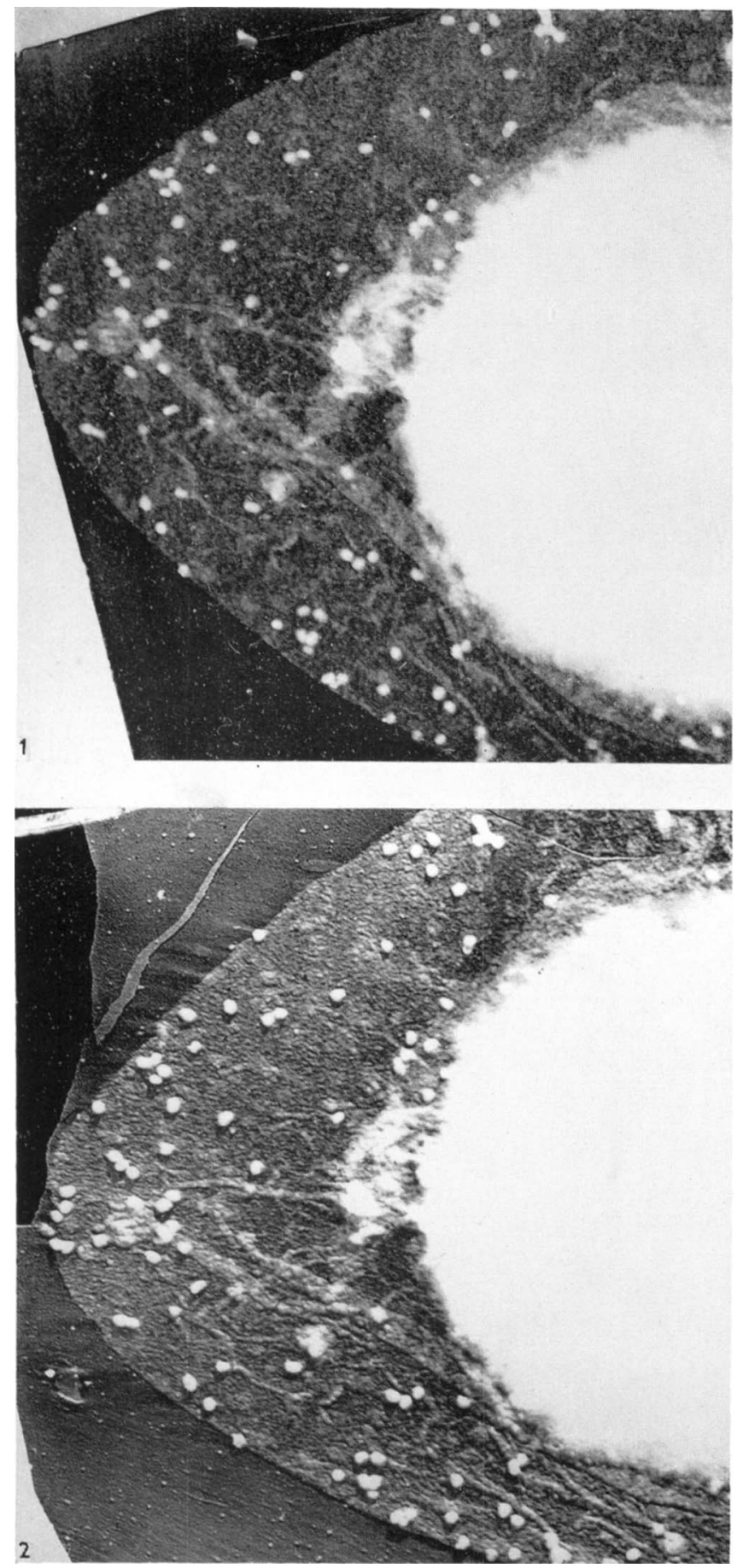

D. A. J. 'Tyrreli \& IR. C. Valintine Assay of inflenequ virus partiches.

PIATE 1

(Facing p. (674) 
Journal of General Microbiology, Vol. 16, No.3
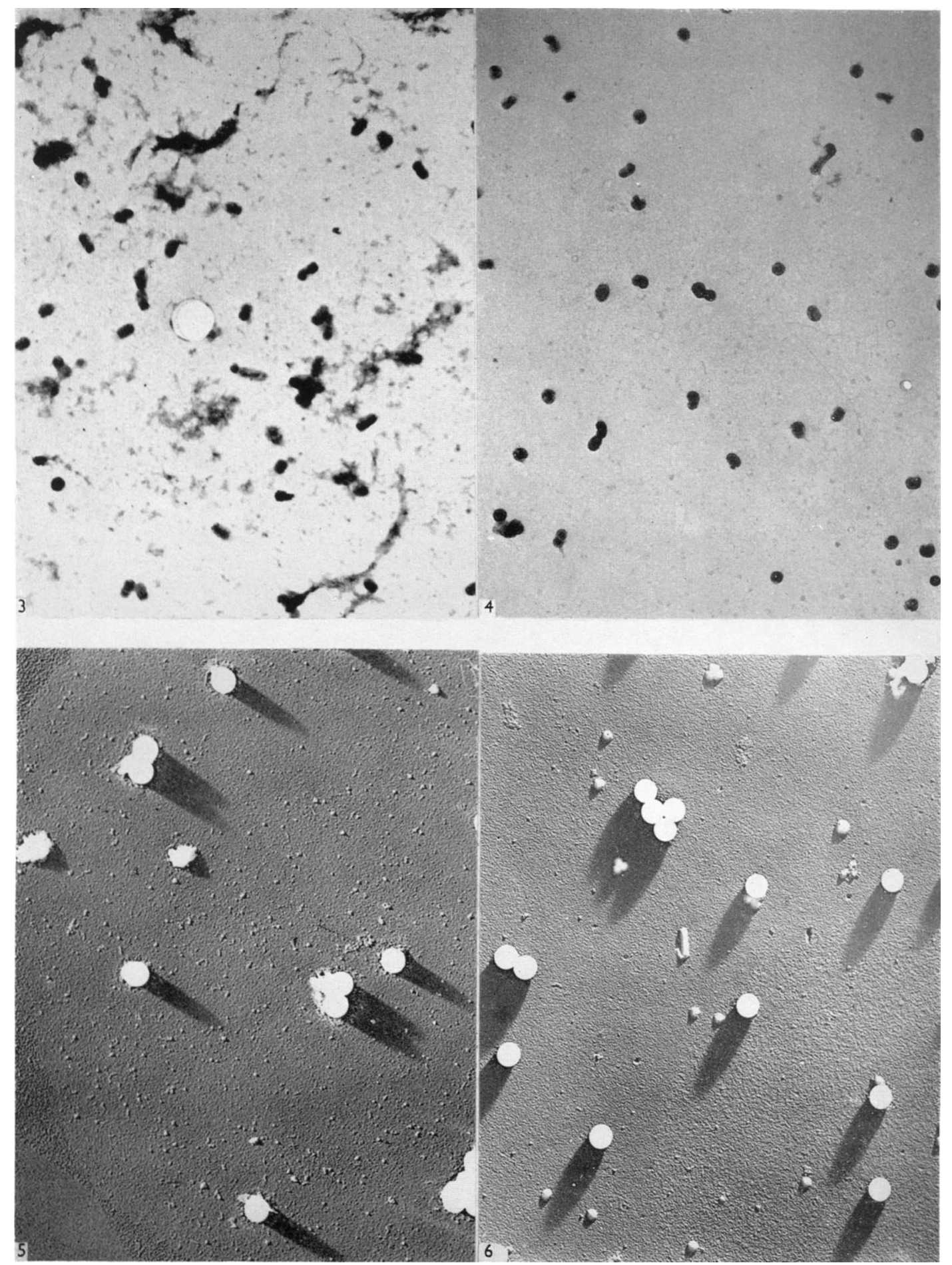

D. A. J. Tyrrell \& R. C. Valentine-Assay of infletexza virus particles. Plate 2 
Reed, L. J. \& Muench, H. (1938). A simple method of estimating fifty per cent end points. Amer. J. Hyg. 27, 493.

Tyrrele, D. A. J. (1955). New tissue culture systems for influenza, Newcastle disease and vaccinia viruses. J. Immunol. 74, 293.

Werner, G. H. \& Schlesinger, R. W. (1954). Morphological and quantitative comparison between infectious and non-infectious forms of influenza virus. J. exp. Med. 100, 203.

Williams, R. C. \& Backus, R. C. (1949). Macromolecular weights determined by direct particle counting. I. The weight of the bushy-stunt virus particle. J. Amer. chem. Soc. 71, 4052.

\section{EXPLANATION OF PLATES}

Plate 1

Fig. 1. Influenza virus particles adsorbed on a lysed hen red blood cell. Fixed with $0 \cdot 1 \%$ osmium tetroxide. Unshadowed. $\times 12,000$.

Fig. 2. The field shown in Fig. 1 after shadowing with gold + palladium; $\times 12,000$.

\section{Plate 2}

Fig. 3. Influenza virus particles (KUNZ strain) as harvested in allantoic fluid with much cell debris. Fixed with osmium tetroxide vapour and treated with $5 \%$ phospho-

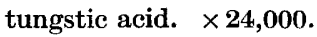

Fig. 4. Influenza virus particles (WS strain) as harvested. Little debris. Fixed with osmium

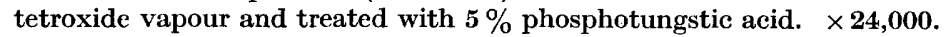

Fig. 5. Part of a spray drop of KUNZ fluid after dialysis mixed with latex spheres. It contained unexpectedly few virus particles but many smaller particles. Shadowed with gold + palladium. $\times 14,000$.

Fig. 6. Part of a spray drop of MEL fluid after dialysis mixed with latex spheres. The virus particles can be clearly identified and counted. Shadowed with gold + palladium. $\times 14,000$.

(Received 10 December 1956) 